\title{
"Analysis of water quality parameters of ground water near Chittorgarh Industrial area, Rajasthan, India"
}

\author{
Naved Ahmed Gauri and Sanjay Kumar Soni, \\ Department of chemical engineering ,Mewar university, NH - 79 Gangrar, Chittorgarh, Rajasthan 312901
}

\begin{abstract}
Ground water is increasingly being sought as a source of drinking water due to the scarcity, nonavailability and bacteriological pollution of surface water. Ground water is a major source for all purposes of water requirements in India and it plays a vital role to human life and economic activity. The occurrence and distribution of ground water in the country varies significantly depending on geology, rainfall and geomorphology. The unplanned and non-scientific development of ground water resources has led to sharp depletion of the resources and also degradation of quality at many places. The present work describes the important results of the physico-chemical analysis of ground water sample of different villages of district Chittorgarth in Rajasthan. The different parameters determined are $p H, T D S$, Chloride, Total alkalinity and Total hardness, Electrical conductivity, Free carbon dioxide. The obtained results are compared with Indian Standard Drinking Water specification IS: 10500-2012 and it indicates that parameters of all ground water samples are in permissible limits except Hardness of Nimbahera. The interesting fact is that the hardness alone is making ground water unfit for drinking.
\end{abstract}

Keywords: Physicochemical analysis, Nimbahera, Ground water, Hardness

\section{Introduction}

Chittorgarh is a city and a municipality in Rajasthan state of western India. It lies on the Berach River, a tributary of the Banas, and is the administrative headquarters of Chittorgharh District and a former capital of the Sisodia Dynasty of Mewar. The city of Chittaurgarh is located on the banks of river Gambhiri and Berach. Chittorgarh has an average elevation of 394 metres (1292 ft). It is located in the southern part of the state of Rajasthan, in the northwestern part of India. It is located beside a high hill near the Gambheri River and between $23^{\circ} 32^{\prime}$ and $25^{\circ} 13^{\prime}$ north latitudes and between $74^{\circ} 12^{\prime}$ and $75^{\circ} 49^{\prime}$ east longitudes in the southeastern part of Rajasthan state.

$98 \%$ of the planet Earths water is in the Oceans, remaining $2 \%$ is fresh water, but $98 \%$ of, which is stored in ice caps at the poles. In other words only $0.04 \%$ of water is available for human being use. Ground water is the important source for irrigation and drinking purpose. Water pollution is an important aspect of environmental pollution ground water is an important natural resource worldwide that exists only on our planet, without this precious resource life on earth would be non-existent.

Good quality water is inadequate even for normal living and is getting contaminated due to domestic wastes, industrial wastes, agricultural wastes, runoff from urban areas and soluble effluents. ${ }^{[1-3]}$

In the last few decades, there has been a tremendous increase in the demand for fresh water due to rapid growth of population and the accelerated pace of industrialization. Human health is threatened by unsanitary conditions through open drain carrying and disposing waste water into natural water bodies. Rapid urbanization, especially in developing countries like India, has affected the availability and quality of groundwater due to its overexploitation and improper waste disposal, especially in urban areas. According to WHO organization, about $80 \%$ of all the diseases in human beings are caused by water ${ }^{[4]}$ Once the groundwater is contaminated, its quality cannot be restored back easily and to device ways and means to protect it. ${ }^{[5-7]}$

\section{Experimental}

The present study provides a detailed description of the chemical criteria of ground water. Seven representative samples of entire study area were collected and analyzed for $\mathrm{pH}$, chloride, total dissolved solids (TDS), total alkalinity, total hardness, electrical conductivity, free carbon dioxide .The sampling sites were identified and then the samples were collected from different sources after allowing some amount of water to flow out. The samples were collected in clean plastic bottles, which were pre cleaned, dried in dust free environment and sterilized. The instruments were used in the limit of précised accuracy and chemicals used were of analytical grade. All the water sample were properly labeled as 1, 2, 3, 4, 5, 6, 7, and a record was prepared indicating the source of the sample, location of the source and data of collection. 
Locations from where water samples were collected are as follows :-

Sample 1. Mewar university, acadmic block

Sample 2. Mewar university, mess area

Sample 3. Adarsh colony, Nimbahera

Sample 4. Chogawdi

Sample 5. Chanderia

Sample 6. Rawlia

Sample 7. Shambhupura

The Parameters and methods selected for the water sample analysis are detailed in Table-1.

Table-1: Different analytical water quality parameters and guideline values as per Indian standard IS 10500:2012. ${ }^{[8]}$

\begin{tabular}{|l|l|l|l|}
\hline Sr no & Parameter & $\begin{array}{l}\text { Indian standard } \\
\text { (Desirable) }\end{array}$ & $\begin{array}{c}\text { Indian standard } \\
\text { (Maximum) }\end{array}$ \\
\hline & Temperature & - & - \\
\hline & $\mathrm{pH}$ & $6.5-8.5$ & No relaxation \\
\hline & Total Hardness (mg/l) & 300 & 600 \\
\hline & Total Alkalinity(mg/l) & 200 & 600 \\
\hline & Chloride(mg/l) & 250 & 1000 \\
\hline & Odour & Unobjectionable & \\
\hline & Total Dissolved Solids(TDS) $(\mathrm{mg} / \mathrm{l})$ & 500 & 2000 \\
\hline
\end{tabular}

\section{Results And Discussion}

The results obtained for urban areas pilani are reported in Table-2. Eight water samples were analyzed for the following eight parameters - $\mathrm{pH}$, temperature,TDS, chloride, total alkalinity, total hardness, free carbondioxide, electrical conductivity.

Table-2: Physio-chemical parameters of sampled waters in Chittorgarh Industrial area.

\begin{tabular}{|c|c|c|c|c|c|c|c|}
\hline \multirow[t]{2}{*}{ Parameters } & \multicolumn{7}{|c|}{ Sampling point } \\
\hline & 1 & 2 & 3 & 4 & 5 & 6 & 7 \\
\hline Temperature $\left({ }^{0} \mathrm{C}\right)$ & 23 & 24 & 31.6 & 31.4 & 32 & 30.5 & 31 \\
\hline pH & 8 & 7.8 & 7.4 & 7.6 & 7.8 & 7.4 & 8.2 \\
\hline Total Alkalinity (mg/l) & 200 & 230 & 145 & 197 & 202 & 165 & 153 \\
\hline Total Hardness (mg/l) & 375 & 370 & 625 & 462.5 & 575 & 350 & 400 \\
\hline Chloride (mg/l) & 250 & 250 & 270 & 260 & 310 & 260 & 280 \\
\hline EC $(\mu \mathrm{mho} / \mathrm{cm})$ & 1180 & 1170 & 2296 & 1424 & 2020 & 1010 & 1128 \\
\hline TDS(mg/l) & 596 & 591 & 1148 & 712 & 1010 & 510 & 564 \\
\hline Free $\mathrm{CO}_{2}(\mathrm{mg} / \mathrm{l})$ & 17 & 18 & 22 & 33 & 44 & 44 & 33 \\
\hline
\end{tabular}

Temperature: Temperature is one of the most essential parameters in water. It has significant impact on growth and activity of ecological life and is greatly affects the solubility of oxygen in water and it also controls the physiological behavior and distribution of organisms. The temperature of ground water has found to be in the range of $23^{\circ}-31^{\circ} \mathrm{C}$.

pH: All chemical and biological reactions are directly dependent upon the $\mathrm{pH}$ of water system. ${ }^{[9]}$ The lower values of $\mathrm{pH}$ may cause tuberculation and corrosion while the higher values may produce incrustation, sediment deposit and difficulties in chlorination for disinfection of water. ${ }^{[10]}$

In the present study the $\mathrm{pH}$ values in all the samples range from 7.4 to 8.2 , which are all within the limit. The $\mathrm{pH}$ of water is very important indication of its quality and provides information in many types of geochemical equilibrium or solubility calculations. ${ }^{[1]}$

TDS: Total dissolved solid is an important parameter for drinking water and water to be used for other purposes. The maximum permissible limit of TDS is $2000 \mathrm{mg} / \mathrm{l}$ (IS 10500:2012). Beyond the prescribed limit, it imparts a peculiar taste to water and reduce its potability. TDS was found in the range of 510 to $1148 \mathrm{mg} / \mathrm{L}$, which is also within the limit.

Chloride: Chloride contents in fresh water are largely influenced by evaporation and precipitation. ${ }^{[\mathbf{1 2 ]}}$ Chloride is the most trouble some anion in the irrigation water. They are generally more toxic than sulphate to most of the plants and are best indicator of pollution. ${ }^{[13-14]}$ Chloride contents varied from $250-310 \mathrm{mg} / \mathrm{l}$ in all the samples, which is all in the limit. 
Total alkalinity: The desirable limit for total alkalinity is $200 \mathrm{mg} / \mathrm{L}$ (IS 10500:2012). The value of water samples varies from 145 to $230 \mathrm{mg} / \mathrm{L}$. In ground water, most of the alkalinity is caused due to carbonates and bicarbonates.

Total hardness: Hardness is an important criterion for determining the usability of water for domestic, drinking and many industrial supplies. The value of water samples varies from 350 to $625 \mathrm{mg} / \mathrm{l}$ which exceed the permissible limit. The maximum permissible limit for total hardness is $600 \mathrm{mg} / \mathrm{l}$. (IS 10500:2012). Water hardness is primarily due to the results of interaction between and the geochemical formations. ${ }^{[15]}$ The hardness of water is due to the presence of alkaline earths such as calcium and magnesium. Higher values of hardness are responsible for incrustation and scaling in pipelines.

Electrical Conductivity: Conductivity is the measure of mineral content and is a numerical expression ability of an aqueous solution to carry electric current. This ability depends on the presence of ions, their total concentration, mobility, valence, relative concentrations and temperature of measurement. In present investigation, lowest value was recorded $1010 \mu \mathrm{mho} / \mathrm{cm}$ and high value was recorded $2296 \mu \mathrm{mho} / \mathrm{cm}$.

Free $\mathrm{CO}_{2}$ : Free carbon dioxide showed an irregular pattern in the groundwater which reflects less load of organic matter in water. In present investigation, lowest value was recorded $17 \mathrm{mg} / \mathrm{l}$ and high value was recorded $44 \mathrm{mg} / \mathrm{l}$.

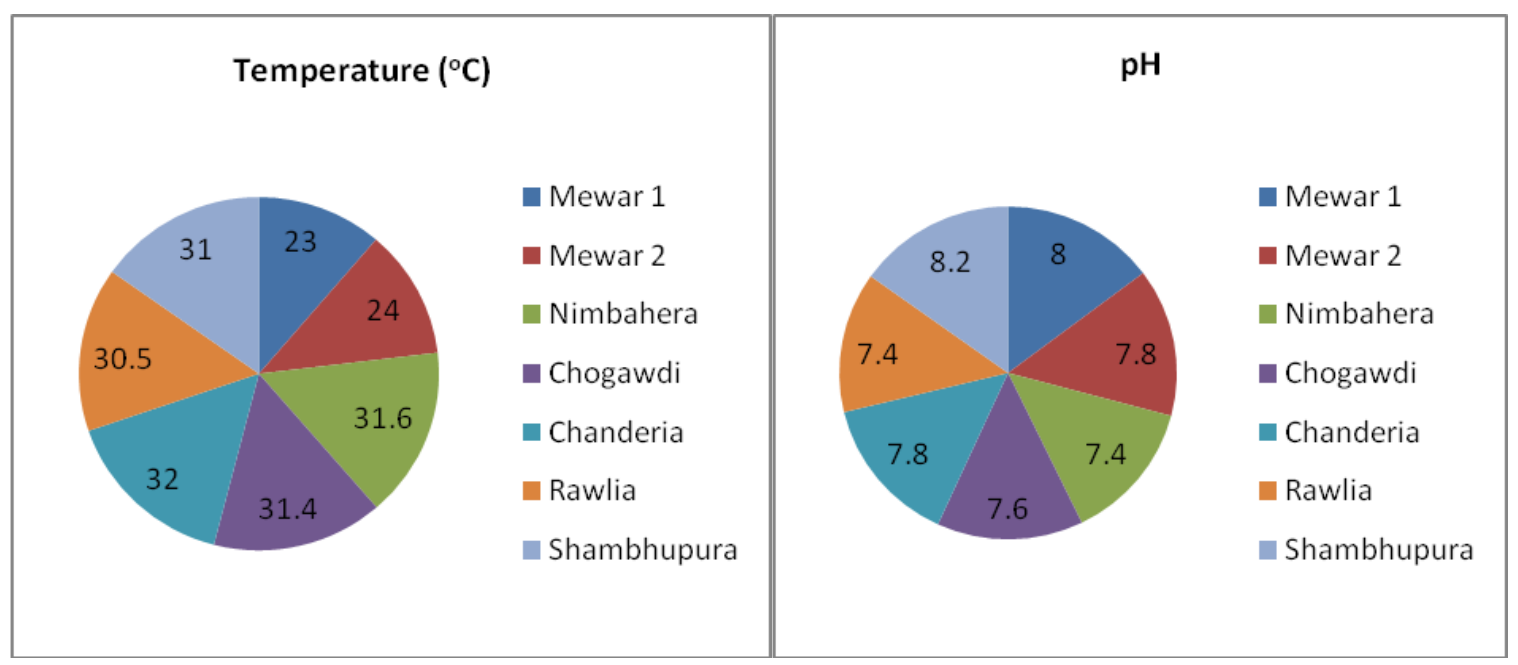

Fig 1: Comparison of the temperature and $\mathrm{pH}$ parameter between different samples of villages

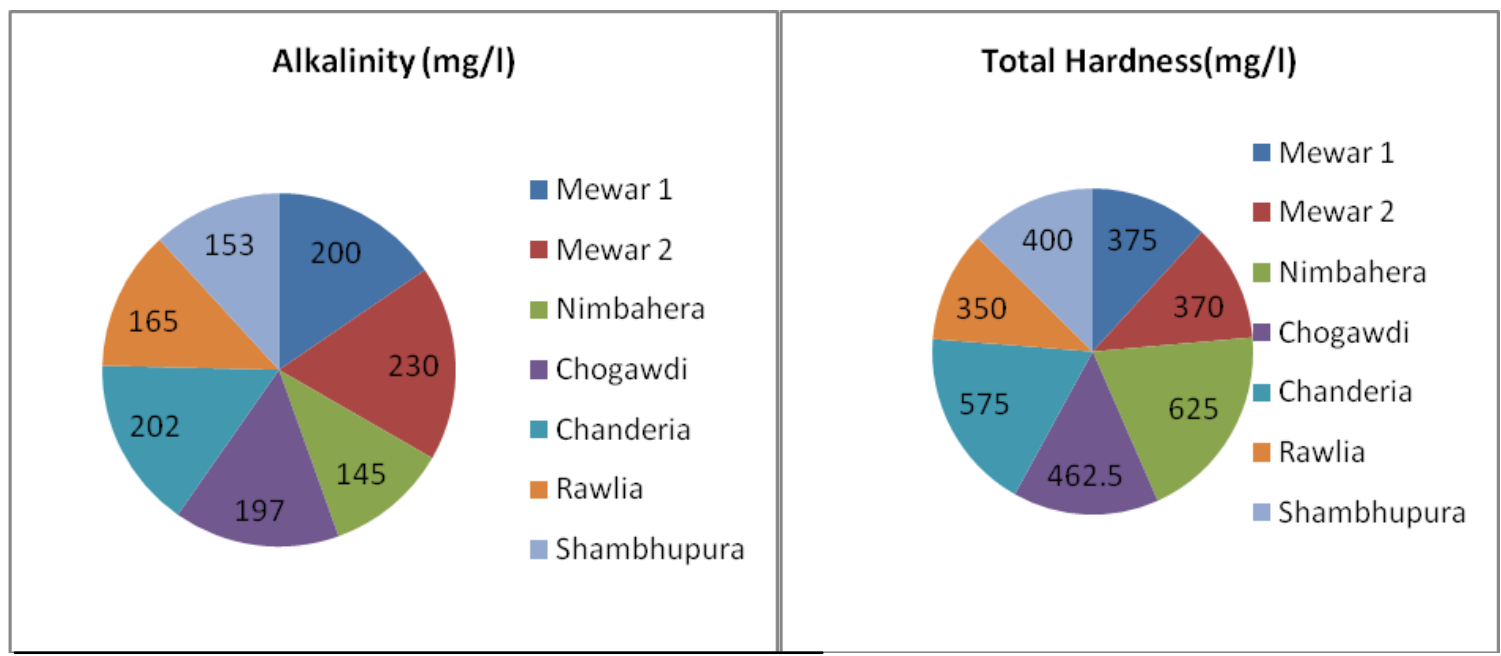

Fig 2: Comparison of the alkalinity and total hardness parameter between different samples of villages 


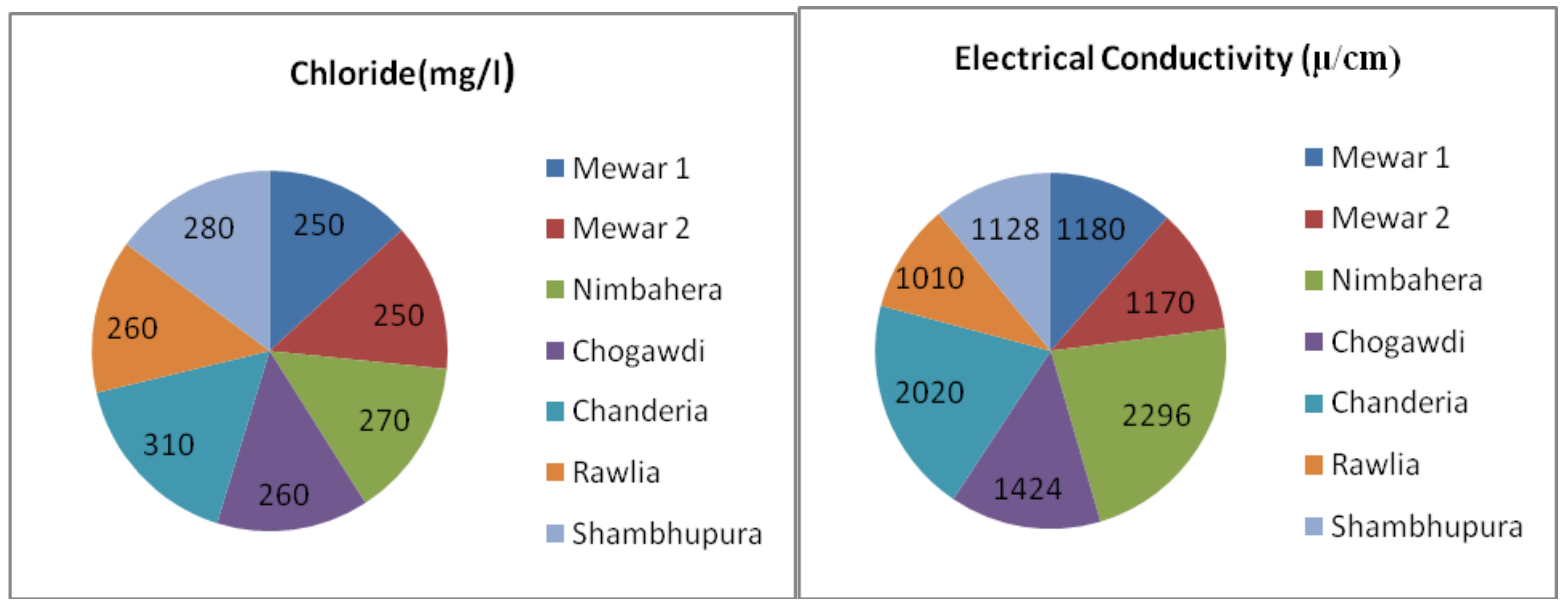

Fig 3: Comparison of the chloride and electrical conductivity parameter between different samples of villages

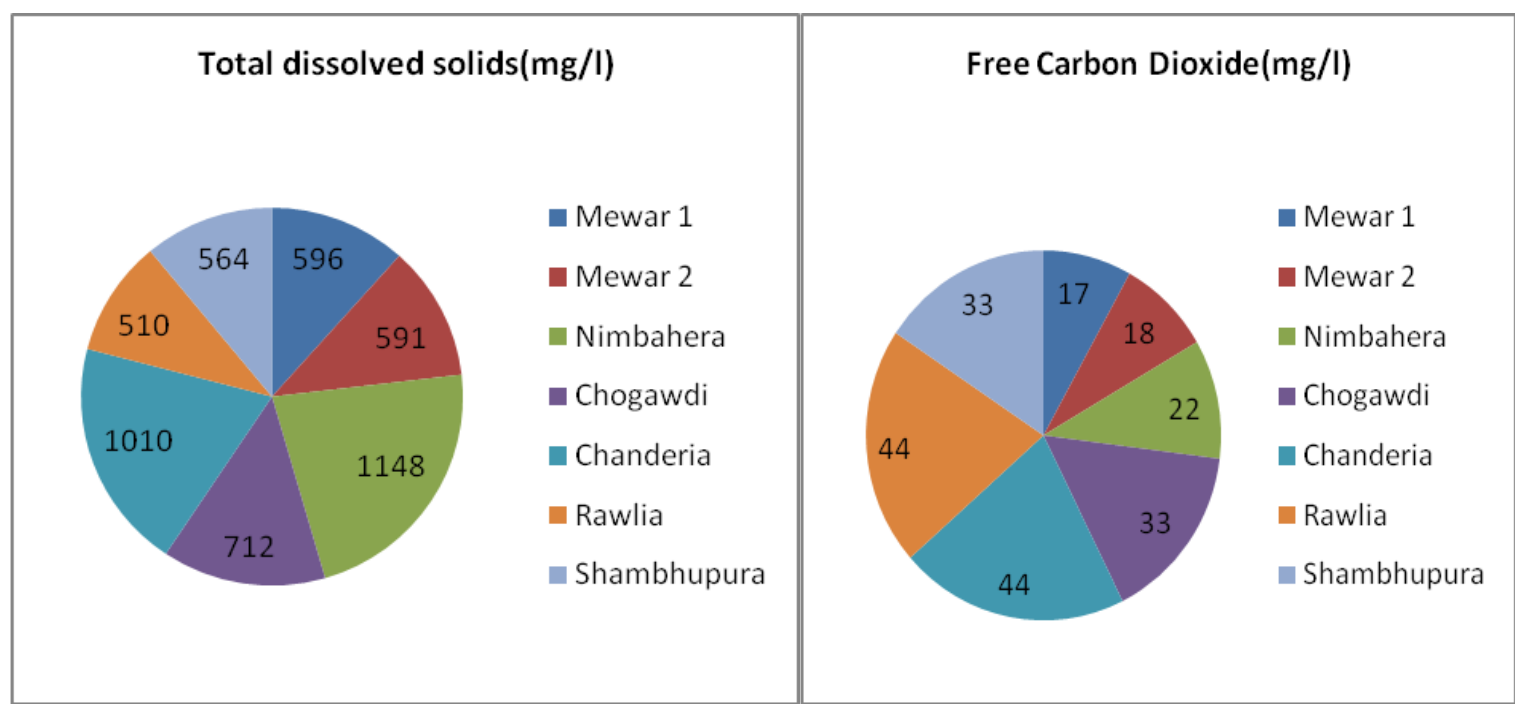

Fig 4: Comparison of the TDS and free Carbon Dioxide parameter between different samples of villages

\section{Conclusion}

Although it was a representative sample study of the ground water quality of surrounding villages of district Chittorgarh, but the results are very alarming. All parameters except hardness were found within permissible limits. The general taste of water is also good. A layman cannot determine the possible hazards of water quality. This fact makes the study important. There is some industrial growth in Chittorgarh and Nimbahera region and the water of Nimbahera is hard, because of this, people of this area are prone for the immediate health problems such as stomach diseases, gastric troubles etc. Irrigation is the main occupation of the surrounding population and chemical fertilizers are more commonly being used. Apart from Nimbahera's ground water, the physical and chemical properties of ground water of rest of the areas were within desirable limits and shall be useful in future management of the reservoir.

[1]. K.Karunakaran et al., Indian J.Env. Prot. 25, 510 (2005)

[2]. W.P.S. Inirabai and S. George, Poll. Res., 21, 209 (2002)

[3]. D.K. Sinha and A.K. Srivastava, Indian J. Environ. Hlth., 37, 205 (1995).

[4]. Nirdosh Patil, Atiq Ahmed, Sureshbabu H, N M Kottureshwar, M. Jayashree, J.Nijalingappa (2010), "Study on the PhysicoChemical characteristics of ground water of Gulbarga City (Karnataka)" International Journal of Applied Biology \& Pharmaceutical Technology, 1(2), AugOct, 519

[5]. M.A. Maniyar (1990), "Evaluation of Groundwater Quality of the Bore wells of Gulbarga city maintained by K.U.W.S. and D. Board. M.E. Environmental Engineering Dissertation Submitted to Gulbarga University Gulbarga”, pp 1629.

[6]. S.R. Mise (1988), "Wastewater Characterization of Gulbarga City (Zones 'A' \& 'B') M.E.,Environmental Engineering Dissertation Work Submitted to Gulbarga University Gulbarga", pp 1233

[7]. Shivasharanappa (1988), wastewater Characterization of Gulbarga City (Zone 'C'). M.E.,Environmental Dissertation Work Submitted to Gulbarga University Gulbarga", pp 4667

[8]. BIS, Specification for drinking water IS :10500: 2012] Bureau of Indian Standards, New Delhi (1983). Indian Standard Specification for Drinking Water, ISI, New Delhi, IS: 10500 (2012). 
[9]. A.Sreenivason, F.A.O. Fish Rep, 44(3), 101 (1967)

[10]. Prasad B. Guru, Evaluation of Water Quality in Tadepalli Mandal of Guntur Distt., A.P., Nature, Environ. and Poll. Techn., 2(3) 273-276 (2003).

[11]. J.D. Hem Scientific Publishers, Jodhpur (1991)

[12]. N. Kumarswamy, Poll. Res., 10, 13 (1991)

[13]. K. Vijayram, S.R. Vyasugi, S.Chitra, and U. Asha, Poll. Res., 9, 133 (1990)

[14]. H. Rai, Archiv Fish Hydrobiol; 75, 369 (1979).

[15]. E.E. Angino, Geochemistry and water quality. Applied Environmental Geochemistry (Ed. Thronton,1), Academic Press London, pp $171(1983)$. 